Article

\title{
The Fabp4-Cre-Model is Insufficient to Study Hoxc9 Function in Adipose Tissue
}

\author{
Sebastian Dommel ${ }^{1, *}$, Claudia Berger ${ }^{1}{ }^{(\mathbb{D}}$, Anne Kunath ${ }^{1}$, Matthias Kern ${ }^{1}$, Martin Gericke ${ }^{2,3}$, \\ Peter Kovacs ${ }^{1} \mathbb{D}$, Esther Guiu-Jurado ${ }^{1}$, Nora Klöting ${ }^{1,4}$ and Matthias Blüher ${ }^{1,4, * \mathbb{C}}$ \\ 1 Medical Department III-Endocrinology, Nephrology, Rheumatology, University of Leipzig Medical Center, \\ D-04103 Leipzig, Germany; claudia.berger@medizin.uni-leipzig.de (C.B.); Kunath.anne@gmx.de (A.K.); \\ matthias.kern@medizin.uni-leipzig.de (M.K.); peter.kovacs@medizin.uni-leipzig.de (P.K.); \\ esther.guiujurado@medizin.uni-leipzig.de (E.G.-J.); nora.kloeting@medizin.uni-leipzig.de (N.K.) \\ 2 Institute of Anatomy, Leipzig University, D-04103 Leipzig, Germany; martin.gericke@medizin.uni-leipzig.de \\ 3 Institute of Anatomy and Cell Biology, Martin-Luther-University, D-06108 Halle (Saale), Germany \\ 4 Helmholtz Institute for Metabolic, Obesity and Vascular Research (HI-MAG) of the Helmholtz Zentrum \\ München at the University of Leipzig and University Hospital Leipzig, Leipzig University, \\ D-04103 Leipzig, Germany \\ * Correspondence: sebastian.dommel@medizin.uni-leipzig.de (S.D.); \\ matthias.blueher@medizin.uni-leipzig.de (M.B.); Tel.: +49-341-9713400 (S.D.); +49-341-9715984 (M.B.)
}

Received: 18 May 2020; Accepted: 26 June 2020; Published: 29 June 2020

\begin{abstract}
Developmental genes are important regulators of fat distribution and adipose tissue (AT) function. In humans, the expression of homeobox c9 (HOXC9) is significantly higher in subcutaneous compared to omental AT and correlates with body fat mass. To gain more mechanistic insights into the role of Hoxc9 in AT, we generated Fabp4-Cre-mediated Hoxc9 knockout mice (ATHoxc9-/-). Male and female ATHoxc $9^{-/-}$mice were studied together with littermate controls both under chow diet (CD) and high-fat diet (HFD) conditions. Under HFD, only male ATHoxc9-/- mice gained less body weight and exhibited improved glucose tolerance. In both male and female mice, body weight, as well as the parameters of glucose metabolism and AT function were not significantly different between ATHoxc $9^{-/-}$ and littermate control CD fed mice. We found that crossing Hoxc9 floxed mice with Fabp4-Cre mice did not produce a biologically relevant ablation of Hoxc9 in AT. However, we hypothesized that even subtle reductions of the generally low AT Hoxc9 expression may cause the leaner and metabolically healthier phenotype of male HFD-challenged ATHoxc9-/- mice. Different models of in vitro adipogenesis revealed that Hoxc9 expression precedes the expression of Fabp4, suggesting that ablation of $H_{0 x c} 9$ expression in AT needs to be achieved by targeting earlier stages of AT development.
\end{abstract}

Keywords: developmental genes; adipose tissue; obesity; adipocytes

\section{Introduction}

An important breakthrough in developmental biology was the discovery that there are common genes that control early embryonic development in organisms ranging from the fruit fly to humans. Edward B. Lewis demonstrated that homeotic genes are of central importance for segmentation in Drosophila melanogaster [1]. Homeotic genes are lined up on the DNA in exactly the same order as they are expressed along the body axis during embryogenesis. As a subset of homeotic genes, Hox genes are considered as master regulators for segmentation patterning during embryogenesis. Humans and mice possess thirty-nine Hox genes organized into four clusters (A to D) on four chromosomes (Hoxa 7p15, Hoxb 7q21.2, Hoxc 12q13, and Hoxd 2q31). Each cluster consists of thirteen paralog groups with nine to eleven members [2]. On each chromosome, the Hox clusters are organized in $3^{\prime}$ to $5^{\prime}$ orientation with paralogous lower number group members (e.g., Hoxa1, Hoxb1, Hoxd1) at the 3' 
end, whereas higher number members are located more in the $5^{\prime}$ direction. During embryogenesis, Hox genes are expressed in a spatial-temporal manner. According to their chromosomal localization, $3^{\prime}$ genes are expressed in more anterior body regions, while in posterior areas, $5^{\prime}$ Hox genes are paramount. Besides, anterior members are expressed earlier than posterior [3,4]. In addition, they act as transcriptional regulators in adult organisms. For this, all homeotic genes are united by the presence of a highly conserved $180 \mathrm{bp}$ DNA-binding domain, called homeobox [5].

Previously, we analyzed expression patterns of developmental control genes in murine adipocytes and stroma vascular fraction (SVF) from both subcutaneous (scWAT) and epididymal white AT (eWAT) depots. Thereby, we detected twelve genes being differentially expressed between both depots, with seven of them showing higher expression levels in eWAT and five genes more expressed in scWAT [6]. Among those AT-expressed developmental genes (Tbx15, Shox2, En1, Sfrp2), we found significantly higher HOXC9 expression in human subcutaneous compared to visceral AT correlating with body fat mass and adipocyte size [6,7]. However, the precise mechanisms by which Hoxc9 may contribute to obesity, AT distribution, and function are not well understood. Because germ line mutations in Hox genes are lethal for the developing embryo, we used the adipocyte-specific Cre-recombinase under control of the fatty acid-binding protein 4 (Fabp4) promotor to create mice lacking Hoxc9 in AT (ATHoxc ${ }^{-/-}$) [8,9]. Subsequently, we characterized the consequences of Hoxc9 deletion in AT on the morphological and metabolic parameters of ATHoxc9-/- mice up to an age of 30 weeks.

\section{Experimental Section}

\subsection{Animal Care and Research Diets}

All animal studies were approved by the local authorities of the state of Saxony, Germany, as recommended by the responsible local animal ethics review board (Landesdirektion Leipzig, TVV15/16, T07/16, T02/19). All mice were housed in pathogen-free facilities in groups of three to five at $22 \pm 2{ }^{\circ} \mathrm{C}$ on a $12 \mathrm{~h} \mathrm{light/dark} \mathrm{cycle.} \mathrm{Animals} \mathrm{were} \mathrm{bred} \mathrm{in} \mathrm{laboratories} \mathrm{at} \mathrm{Leipzig} \mathrm{University} \mathrm{and} \mathrm{were}$ fed a standard chow diet (CD, Ssniff Spezialdiäten, Soest, Germany) containing 38.2\% carbohydrates, $21.2 \%$ proteins, and $3.8 \%$ fat (10\% calories from fat). Diet-induced obesity was achieved by feeding a high-fat, high-sucrose diet (HFD, Diet Identification No. D12492; Research Diets, produced by Ssniff Spezialdiäten) containing $26.2 \%$ carbohydrates, $26.3 \%$ protein, and $34.9 \%$ fat ( $60 \%$ calories from fat) starting at 6 weeks of age. All animals had ad libitum access to food and water at all times, except for experiments where a fasting state was required.

\subsection{Generation of AT-Specific Hoxc9 Knockout Mice}

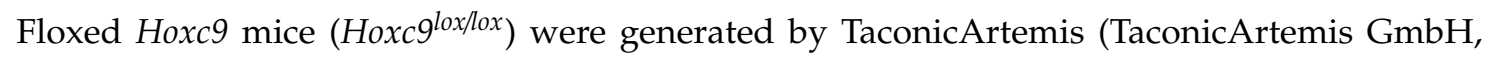
Cologne, Germany) (Figure 1). The loxP-flanked Hoxc9 allele was generated in C57BL/6NTac embryonic stem cells by transfecting them with the targeting vector. Besides floxed Hoxc9 exons 2 and 3, the vector contained thymidine kinase as negative and two positive selection markers: an FRT flanked neo cassette and a puro cassette circumscribed by F3 sites. After removal of positive selection markers in vivo by Flp-mediated recombination, ATHoxc $9^{-/-}$were derived by crossing Hoxc $9^{\text {lox } / w t}$ mice with Hoxc $9^{\text {lox/wt }}$ mice expressing the Cre recombinase under the control of the Fabp4 promoter/enhancer [10]. In AT, Cre recombinase mediates the deletion of all loxP-flanked alleles, resulting in an AT-specific Hoxc9 knockout (ATHoxc9-/). Animals were backcrossed on a C57BL/6NTac background for at least five generations, and both sexes were included in all experiments. 
Mouse genomic locus

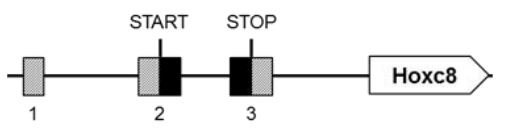

Targeting vector

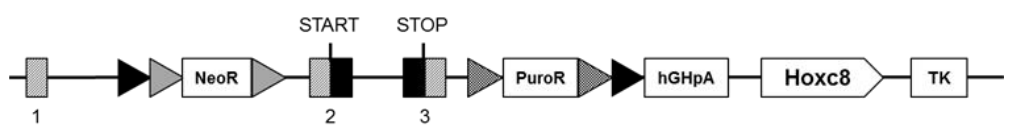

Targeted allele

(after HR)

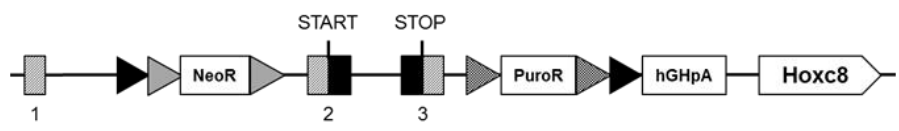

Conditional KO allele (after Cre recombination)

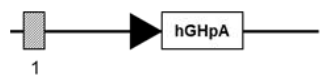

— Mouse genomic region

Hoxc9 untranslated region

Hoxc9 coding region

IoxP site

FRT site
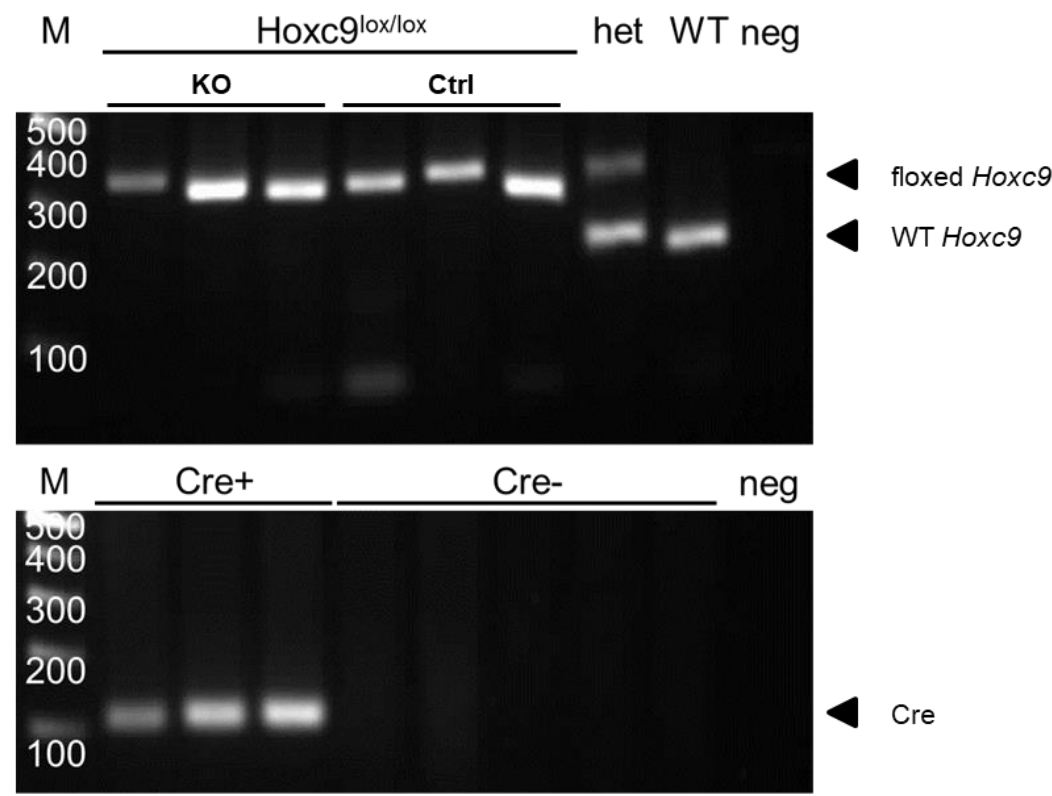

Figure 1. Targeting strategy for the generation of ATHoxc $9^{-/-}$mice. (A) Schematic representation of the genomic Hoxc9 locus with the neighboring Hoxc8 locus, the targeting vector, and the loxP-flanked Hoxc9 allele after homologous recombination (HR) before and after crossing with transgenic mice expressing Cre recombinase under the control of the Fabp 4 promotor. The targeting vector consists of a $5.3 \mathrm{~kb}$ loxP-flanked region containing Hoxc9 exons 2 and 3, a thymidine kinase cassette (TK) as a negative selection marker, and two positive selection markers: a neomycin resistance cassette (NeoR) flanked by FRT sites and a puromycin resistance cassette (PuroR) flanked by F3 sites. The knockout allele (KO) is characterized by loss of Hoxc9's coding region located in exons 2 and 3. (B) Agarose gel electrophoresis after PCR of genomic DNA from homozygous floxed Hoxc9 (Hoxc9lox/lox, predicted PCR product of $324 \mathrm{bp}$ ), wild-type (WT, Hoxc9wt/wt , predicted PCR product of $205 \mathrm{bp}$ ), heterozygous Hoxc9 (Hoxc9lox/wt, predicted PCR products of 205 and $324 \mathrm{bp}$ ), and Fabp4-Cre ${ }^{+}$mice $\left(\mathrm{Cre}^{+}\right.$, predicted product of $100 \mathrm{bp}$ ). Negative control lane without genomic DNA (neg). Arrows indicate PCR products.

\subsection{Molecular Characterization and Genotyping of ATHoxc $9^{-/}$Mice}

Genotyping was performed by PCR using genomic DNA isolated from the tail tip or ear stamp by using the DirectPCR (Tail) Lysis Reagent (Viagen Biotech Inc., Los Angeles, CA, USA). Primer pairs for genotyping are listed in Table S1. PCR was performed as follows: initial denaturation at $95{ }^{\circ} \mathrm{C}$ for $15 \mathrm{~min}$, following 35 cycles of denaturation $95^{\circ} \mathrm{C}$ for $30 \mathrm{~s}$, annealing $60^{\circ} \mathrm{C}$ for $30 \mathrm{~s}$, elongation $72{ }^{\circ} \mathrm{C}$ for 
$1 \mathrm{~min}$, and final elongation $72{ }^{\circ} \mathrm{C}$ for $10 \mathrm{~min}$ using the FastStart PCR Master (Roche, Basel, Switzerland), primer (biomers.net, Ulm, Germany) and a Peltier Thermal Cycler PTC-200 (Bio-Rad, Hercules, CA, USA). On $2 \%$ agarose gel, wild-type mice showed a $205 \mathrm{bp}$ band, whereas Hoxc9lox/lox mice produced a $324 \mathrm{bp}$ band. Additionally, ATHoxc $9^{-/-}$mice showed a $100 \mathrm{bp}$ band for the presence of Cre recombinase. DNA from AT samples was isolated using the NucleoSpin DNA Lipid Tissue Kit (Macherey-Nagel $\mathrm{GmbH} \&$ Co. KG, Düren, Germany) according to the manufacturer's instructions. DNA concentration was quantified with a NanoVue Plus spectrophotometer (GE Healthcare, Chicago, IL). For PCR reactions, $75 \mathrm{ng}$ of DNA were used in combination with primer pairs for Hoxc9 loxP sites, Cre recombinase, and Hoxc9 intron 1 exon 2 junction (Table S1). The following PCR conditions were used: initial denaturation $95^{\circ} \mathrm{C}$ for $3 \mathrm{~min}$ followed by 30 cycles of denaturation $95^{\circ} \mathrm{C}$ for $30 \mathrm{~s}$, annealing $60^{\circ} \mathrm{C}$ for $30 \mathrm{~s}$, elongation $72^{\circ} \mathrm{C}$ for $30 \mathrm{~s}$, and final elongation $72^{\circ} \mathrm{C}$ for $10 \mathrm{~min}$.

\subsection{Phenotypic Characterization}

All experimental procedures were conducted both in male and female mice. In this study, 19 male and 20 female $A T H o x c 9^{-/-}$mice were obtained and compared to 11 male and 16 female control littermates (Hoxc $9^{\text {lox/lox }}$. Mice were studied from an age of 4 weeks up to 30 weeks under CD or up to 26 weeks of age on HFD. Body weight was recorded weekly, and whole-body fat and lean mass were determined with the EchoMRI700 ${ }^{\mathrm{TM}}$ instrument (Echo Medical Systems, Houston, TX, USA) at the respective study's end. At an age of 16 weeks, both sexes underwent a food intake measurement over a time period of 1 week. The daily food intake was calculated as the average intake of chow within the time stated. Intraperitoneal insulin tolerance tests (i.p. ITTs) and glucose tolerance tests (i.p. GTTs) were performed at the age of 25 weeks as previously described [11]. Hyperinsulinemic-euglycemic clamp was performed at 23 - 25 weeks of age as described before [11]. In subgroups, whole body energy metabolism was investigated using an indirect metabolic chamber system (CaloSys V2.1, TSE Systems, Bad Homburg, Germany) at an age of 25 weeks (HFD) or 29 weeks (CD). In brief, 6 to 8 ATHoxc $9^{-/-}$ and $A T H o x_{c} 9^{\text {lox/lox }}$ mice of each sex and diet (CD and HFD) were housed for $72 \mathrm{~h}$ in metabolic chambers as previously described [11]. Body length (naso-anal length) and rectal body temperature (TH-5 Thermalert Monitoring Thermometer Physitemp, Clifton, NJ, USA) were measured at the end of observation period. Mice were sacrificed at the age of 30 weeks (CD) or 26 weeks (HFD) by an overdose of anesthetic (Isoflurane, Baxter, Unterschleißheim, Germany). Liver, brown (BAT), inguinal (ingWAT), and epigonadal white adipose tissue (eWAT) were removed, weighed, and immediately stored in liquid nitrogen or in $4 \%$ formalin for histological investigations. Relative organ weights (liver, BAT, ingWAT, and eWAT) were calculated in relation to body weight.

\subsection{Blood and Serum Analytical Procedures}

Fasting blood glucose levels were obtained from whole venous blood samples using FreeStyle Freedom lite (Abbott $\mathrm{GmbH}$, Ludwigshafen, Germany). $20 \mu \mathrm{L}$ of whole blood were collected in EDTA-containing tubes for HbA1c analyses (COBAS 7000, Roche, Basel, Switzerland). Insulin (Mouse Ultrasensitive Insulin ELISA, ALPCO, Salem, NH), leptin (Mouse Leptin ELISA Kit, CRYSTAL CHEM INC., Downers Grove, IL, USA), and adiponectin (Adiponectin (mouse) ELISA Kit, AdipoGen ${ }^{\circledR}$ LIFE SCIENCES, Liestal, Switzerland) serum concentrations were measured by ELISA using mouse serum according to the manufacturer's guidelines. Serum protein levels were determined by OLINK proteomics (Uppsala, Sweden).

\subsection{Histology}

AT was fixed in $4 \%$ buffered formaldehyde, rinsed with water, and dehydrated in a graded series of $70-100 \%$ ethanol followed by ROTI ${ }^{\circledR}$ Histol (Carl Roth GmbH, Karlsruhe, Germany) and paraffin. Multiple $5 \mu \mathrm{m}$ sections (separated by $80 \mu \mathrm{m}$ after 3 sections) were obtained from ingWAT and eWAT pads, H\&E stained, and analyzed systematically with respect to adipocyte size using a Keyence 
BZ-X800 microscope and BZ-X800 Analyzer software (Keyence Corp., Osaka, Japan). At least 750 (CD) or 1000 (HFD) adipocytes were analyzed for each genotype to determine the cell size distribution.

\subsection{RNA Isolation and Tissue-Specific mRNA Expression}

Frozen AT was lysed using QIAzol Lysis Reagent (Qiagen GmbH, Hilden, Germany) and Precellys Homogenizer (Bertin Technologies, Montigny-le-Bretonneux, France) for $2 \times 20$ s, 5000 rpm. RNA was isolated from tissue homogenates with RNeasy Lipid Tissue mini Kit (Qiagen GmbH, Hilden, Germany). Quantity and quality were determined using a NanoVue Plus spectrophotometer (GE Healthcare, Chicago, IL, USA). $2 \mu \mathrm{g}$ of total RNA were reverse transcribed using Random Primers (Invitrogen, Carlsbad, CA, USA) and Superscript II Reverse Transcriptase (Invitrogen, Carlsbad, CA, USA). Quantitative real-time PCR (qRT-PCR) was performed applying a LightCycler 480 system and LightCycler 480 SYBR Green I Master (Roche, Basel, Switzerland). Hoxc9 mRNA expression was calculated relative to 3664 RNA using the Pfaffl method [12]. Primers are listed in Table S1.

\subsection{Western Blot Analysis}

For Western blot analyses, frozen tissues were homogenized in the radioimmunoprecipitation assay buffer containing a complete ULTRA protease inhibitor cocktail tablet (Roche, Basel, Switzerland) per $10 \mathrm{~mL}$ with Precellys Homogenizer (Bertin Technologies, Montigny-le-Bretonneux, France). The homogenate was centrifuged for $15 \mathrm{~min}$ at $4{ }^{\circ} \mathrm{C}$ and 10,000 rpm. Protein concentration was measured using ROTI ${ }^{\circledR}$ Quant (Carl Roth $\mathrm{GmbH}$, Karlsruhe, Germany) and a Tecan Sunrise microplate reader (Tecan Group Ltd., Männedorf, Switzerland). $20 \mu \mathrm{g}$ of each sample were separated by SDS-PAGE using 4 - 20\% Mini-PROTEAN TGX Precast Protein Gels (Bio-Rad, Hercules, CA, USA) and transferred to Amersham ${ }^{\mathrm{TM}}$ Hybond ${ }^{\mathrm{TM}}$ PVDF membranes (GE Healthcare, Chicago, IL, USA). Non-specific protein binding was blocked with $5 \%(w / v)$ BSA in TBS-T for $1 \mathrm{~h}$. The following antibodies were incubated at $4{ }^{\circ} \mathrm{C}$ overnight to detect specific protein expression: $\beta$-actin (Sigma, A5060, 1:500), Fabp4 (Abcam, ab92501, 1:2000), Hoxc9 (ThermoFisher Scientific, PA-67618, 1:500), and vinculin (Abcam, ab129002, 1:10,000), followed by an incubation of $1 \mathrm{~h}$ at RT with goat anti-rabbit IgG HRP-conjugated (Cell Signaling, CS7074, 1:2000). Protein-antibody interactions were visualized using Pierce ECL Western Blotting Substrate (Thermo Fisher, Waltham, MA, USA) and a g:box system (Syngene, Cambridge, UK).

\subsection{Post-Natal Investigations of Hoxc9 and Fabp4 $m R N A$ and Protein Expressions}

IngWAT was dissected from wild-type C57BL/6NTac mice of 0, 2, 5, 10, 15, and 20 days of age, immediately frozen in liquid nitrogen, and stored at $-80^{\circ} \mathrm{C}$. RNA and proteins were isolated, and levels of gene and protein expression were measured as described under Sections 2.7 and 2.8.

\subsection{Flow Cytometry Analysis}

Flow cytometry analyses were performed as described in Braune et al. [13]. In brief, freshly dissected eWAT from chow-fed animals was digested using collagenase type II (Worthington Biochemical, Lakewood, NJ, USA). The resulting cell suspension was filtered through a $70 \mu \mathrm{m}$ mesh, followed by an erythrocyte lysis using BD lysis buffer (BD Biosciences, Franklin Lakes, NJ, USA), and afterwards, a blocking of Fc receptors by anti-CD16/32 (1:100, Invitrogen, Carlsbad, CA, USA) for $10 \mathrm{~min}$ on ice was performed. Leukocytes were stained by anti-CD45-APC-eFluor 780 (1:100, Invitrogen, Carlsbad, CA, USA). Macrophage populations were stained by anti-F4/80-PE-Cy7 (1:100, Invitrogen, Carlsbad, CA, USA), as well as anti-CD11c-PE (1:100, eBioscience/Thermo Fisher, Waltham, MA, USA) and anti-CD206-Alexa Fluor 647 (1:50, Bio-Rad, Hercules, CA, USA). Lymphocyte populations were stained by anti-CD3-PE-Cy7 (1:50, BioLegend, San Diego, CA, USA), anti-CD4-PE (1:100, BioLegend, San Diego, CA, USA), and anti-CD8b-Alexa Fluor 647 (1:100, BioLegend, San Diego, CA, USA). Isotype controls were implemented by using Armenian hamster IgG isotype control-PE (1:100, eBioscience/Thermo Fisher, Waltham, MA, USA), rat IgG2a negative control-Alexa Fluor 647 (1:50, AbD serotec/Bio-Rad, Hercules, CA, USA), IgG2a, $\mathrm{k}$ isotype control-PE (1:100, BioLegend, 
San Diego, CA, USA), or IgG2b, $\mathrm{k}$ isotype control-Alexa Fluor 647 (1:100, BioLegend, San Diego, CA, USA). All antibody incubations were done in the dark for 20 min on ice. Finally, DNA staining was realized by 7-amino-actinomycin D (7-AAD). Viable $\mathrm{CD}^{+} 5^{+}$and $\mathrm{F} 4 / 80^{+}$cells were defined as adipose tissue macrophages (ATMs). Subpopulations could be further distinguished into M1 (CD11 ${ }^{+}$; $\left.\mathrm{CD} 206^{-}\right)$and M2 $\left(\mathrm{CD} 11 \mathrm{c}^{-} ; \mathrm{CD} 206^{+}\right)$. Viable $\mathrm{CD}^{+} 5^{+}$and $\mathrm{CD}^{+}$cells were defined as T lymphocytes, further divided into $\mathrm{T}$ helper cells $\left(\mathrm{T}_{\mathrm{H}} ; \mathrm{CD}^{+} ; \mathrm{CD}^{-}\right)$and cytotoxic $\mathrm{T}$ cells $\left(\mathrm{T}_{\mathrm{C}} ; \mathrm{CD}^{-} ; \mathrm{CD} 8^{+}\right)$. Analysis was performed using LSR II (BD Biosciences, Franklin Lakes, NJ, USA) and FACSDiva software 8.0. Quantification was performed using FlowJo 10.0.5 (Tree Star, Ashland, OR, USA).

\subsection{Cell Culture}

For in vitro experiments, 3T3-L1 cells, immortalized epididymal and inguinal adipocytes (kindly provided by Prof. Johannes Klein, Lübeck, Germany), as well as primary cells of the stromal vascular fraction (SVF) were used. SVF cells were gained from scAT of wild-type C57BL/6NTac mice. AT was dissected, lymph nodes removed, and the tissue transferred into DMEM containing gentleMACS ${ }^{\mathrm{TM}}$ tubes, minced and digested by collagenase using a gentleMACS ${ }^{\mathrm{TM}}$ Octo Dissociator with Heaters (Miltenyi Biotec $\mathrm{GmbH}$, Teterow, Germany) at $37^{\circ} \mathrm{C}$ for $40 \mathrm{~min}$. The resulting homogenate was spun down for $10 \mathrm{~min}$ at $300 \mathrm{rpm}$, and sedimented SVF cells were cultured like 3T3-L1 cells. 3T3-L1 cells were cultured and differentiated as described earlier [14]. Immortalized epididymal and inguinal adipocytes were cultured according to the protocols reported by Klein et al. $[15,16]$. Differentiation was initiated after cell layers reached $100 \%$ confluence. Cell lines were harvested at $80 \%$ pre-confluence, at day 0 (=day of induction, 100\% confluence), and every second day until day 8 after induction. Primary cells were harvested at $80 \%$ confluence and at days $0,2,5,8$, and 13 . RNA and proteins were isolated using the AllPrep DNA/RNA/Protein kit (Qiagen GmbH, Hilden, Germany) according to the manufacturer's instructions. Gene and protein expression analyses were performed as described above.

\subsection{Statistical Analysis}

Statistical analyses were performed using Prism 6.0 software (GraphPad Software, San Diego, CA, USA). Data are given as the means \pm SD or SEM. Data were analyzed using a two-tailed unpaired Student's $t$-test or one-way ANOVA. $p$-values $<0.05$ were considered statistically significant.

\section{Results}

\subsection{Generation of ATHoxc $9^{-1-}$ Mice}

ATHoxc -/- $^{-1}$ mice were generated by crossing mice carrying the loxP-flanked Hoxc9 allele with transgenic mice expressing Cre recombinase under the control of the adipocyte-specific Fabp 4 promoter. The knockout strategy is shown in Figure 1A. Mice were genotyped by PCR of genomic DNA followed by agarose gel electrophoresis. According to the PCR product, mice were classified as wild-type $\left(H_{0 x c} 9^{\mathrm{wt} / \mathrm{wt}}, 205 \mathrm{bp}\right)$, heterozygous (Hoxc $9^{\text {lox/wt }}, 205 \mathrm{bp}$ and $\left.324 \mathrm{bp}\right)$, or homozygous (Hoxc9lox/lox, $324 \mathrm{bp}$ ) for the loxP-flanked Hoxc9 allele (Figure 1B). Furthermore, mice were genotyped for the presence of Cre recombinase (Figure 1B). Hoxc $9^{\text {lox/lox }}$ mice were used as controls (Ctrl), whereas mice presenting both Cre recombinase and homozygous loxP-flanked Hoxc9 were considered knockouts (ATHoxc $9^{-1}, \mathrm{KO}$, Figure 1B).

\subsection{Limitations of Fabp4-Cre-Mediated Hoxc9 Targeting}

We systematically assessed Hoxc9 knockdown efficiency on DNA, RNA, and protein levels (Figure 2). Genotyping of AT from Ctrl and ATHoxc $9^{--}$mice could be clearly distinguished from Hoxc9lox/lox and Fabp4-Cre controls (Figure 2A). However, qRT-PCR analyses of Hoxc9 mRNA expression in BAT, ingWAT, and eWAT showed highly heterogeneous expression patterns in both ATHoxc $9^{-/-}$and control mice (Figure 2B). Finally, in Western Blot analyses, the clearly distinct Hoxc9 genotype was not 
associated with significantly lower Hoxc9 protein levels in WAT of ATHoxc9-/- compared to control mice (Figure 2C). Assuming that at the end of study, we could confirm Hoxc9 ablation in a sufficient number of ATHoxc $9^{--}$mice, we systematically characterized the phenotype of ATHoxc9-/- compared to control mice.
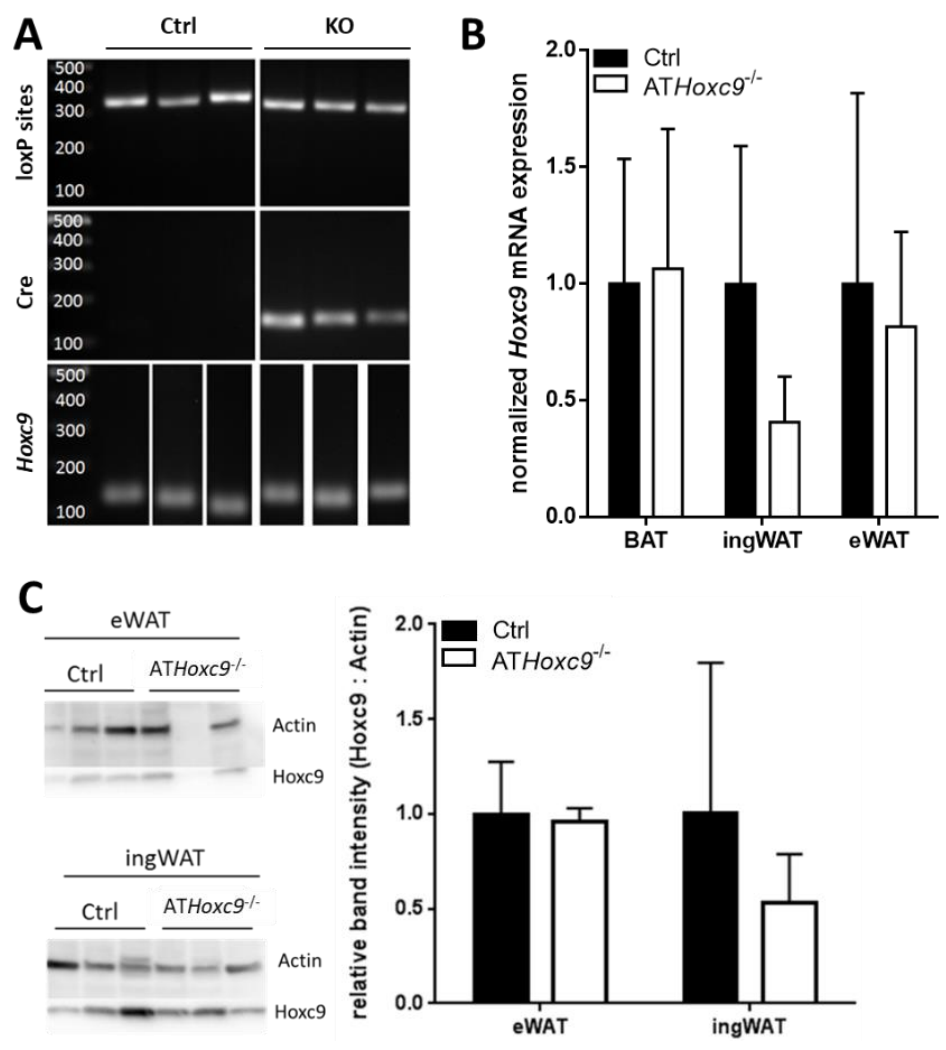

Figure 2. Detection of Hoxc9 in adipose tissue. (A) Agarose gel electrophoresis of PCRs performed with genomic DNA isolated from inguinal white adipose tissue (ingWAT) of control (Hoxc9lox/lox and Fabp4-Cre ${ }^{-}$and ATHoxc9-/- $\left(\mathrm{Hoxc}_{\mathrm{Clox} / \mathrm{lox}}\right.$ and Fabp4-Cre $\left.{ }^{+}\right)$mice. Both control and ATHoxc9-/- mice showed a heterozygous Hoxc9lox/lox product of 324 bp representing floxed Hoxc9 exons 2 and 3 (loxP sites). Products of $\sim 100$ bp revealing Fabp4-Cre recombinase were just present in ATHoxc9-- animals (Cre). Finally, a product of $115 \mathrm{bp}$ illustrating a DNA fragment in between the Hoxc9 intron 1 exon 2 junction was detectable in both control and ATHoxc9-- mice (Hoxc9). (B) Hoxc9 gene expression patterns in murine AT depots were measured using LightCycler 480 and SybrGreen I assay relative to 36B4 expression and normalized to Hoxc $9^{\text {lox/lox }}$ animals. Expression values were calculated according to Pfaffl et al. (2001) [12]. $n=8$ per tissue and genotype. Both sexes and diets included. (C) Protein levels in epididymal white AT (eWAT) and ingWAT were determined using western blot followed by densitometric analysis using GeneTools 4.3 .8 software (Syngene, Cambridge, UK). Hoxc9 band intensities are presented relative to actin levels and normalized to Hoxc $9^{\text {lox/lox }}$ mice.

\subsection{Male ATHoxc9-- Mice are Partially Protected Against Diet-Induced Obesity}

Under chow diet conditions, ATHoxc $9^{-/-}$and control mice of both genders exhibited normal growth until the age of 30 weeks (Figure 3A and Figure S2A). Male ATHoxc ${ }^{-/-}$mice fed with HFD for 20 weeks gained significantly less weight compared to control mice (Figure 3A). However, relative tissue weights and body fat mass were not significantly different between ATHoxc $9^{--}$and control mice after HFD (Figure 3B,C). Lean mass, as well as body length were not different between ATHoxc9 ${ }^{-/}$and control mice or as a function of different diets (Figure 3D-E). In contrast, female ATHoxc9-/- mice were not different from controls regarding body weight or fat mass (Figure S2). Daily food intake was indistinguishable between ATHoxc $9^{-/-}$and control mice in both sexes (Figure 3F and Figure S2F). 

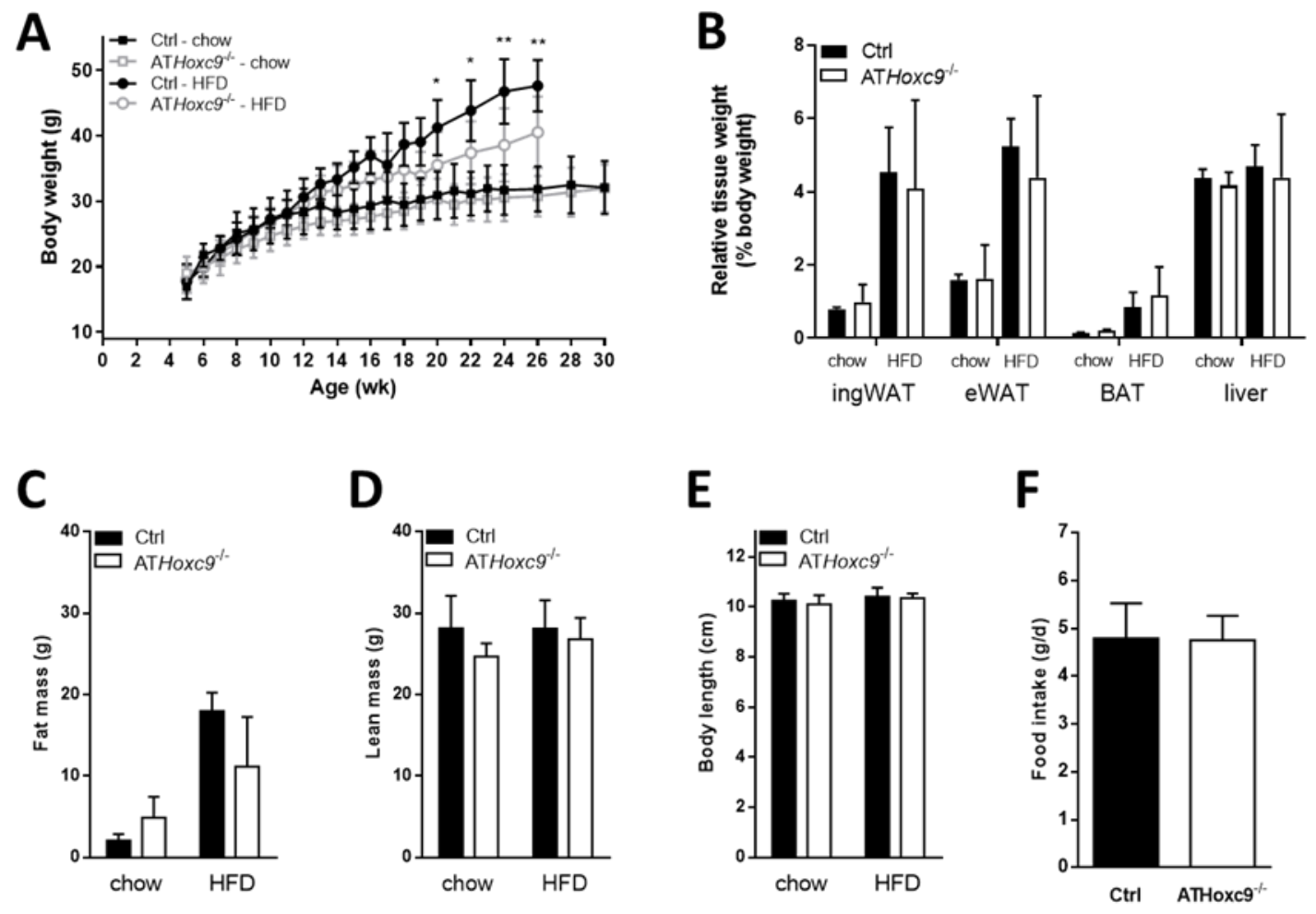

Figure 3. Phenotyping of male ATHoxc9 deficient mice. (A-F) Body weight gain, relative tissue weights, fat and lean mass, as well as body length and food intake do not differ between ATHoxc $9^{-/-}$and control male mice, except body weight differences under high-fat diet (HFD). ${ }^{*} p<0.05,{ }^{* *} p<0.01$. BAT, brown AT.

\subsection{Consequences of ATHoxc9-- on AT Morphology and Inflammation}

Histological analyses of both ingWAT and eWAT revealed that ATHoxc9-/- mice had significantly smaller adipocytes under chow diet (CD) conditions (Figure 4A-C). Under HFD, adipocytes from eWAT of ATHoxc - $^{-/}$mice became significantly larger compared to those of control mice, whereas no adipocyte size difference was detectable between the genotypes in ingWAT (Figure 4E-H). Analyses of adipocyte size distribution only revealed a genotype difference in ingWAT and eWAT uponCD (Figure 4B-D,F-H). There were no differences in AT macrophage or $\mathrm{CD}^{+}$and $\mathrm{CD} 8^{+}$lymphocyte numbers, nor the ratio of M1 to M2 macrophage subpopulations in eWAT between ATHoxc $9^{-/-}$and control mice (for males: Figure 4I-K and for females: Figure S3A-C). In both sexes, the total number of leukocytes (CD45 positive cells) was not different between ATHoxc $9^{-/-}$and control mice. Moreover, we did not find histological evidence for differences in AT immune cell infiltration between ATHoxc $9^{-/-}$and control mice after HFD by conventional H\&E staining. Based on that observation, we did not perform additional AT immunohistochemistry analyses. 
A

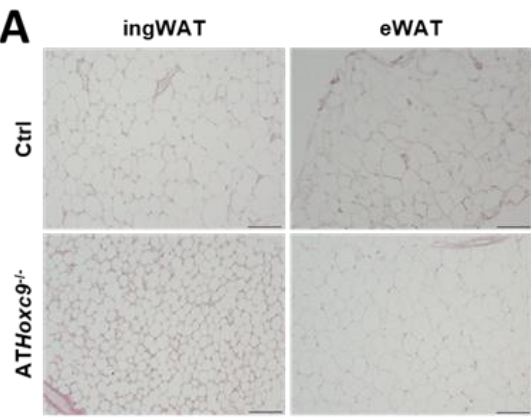

B
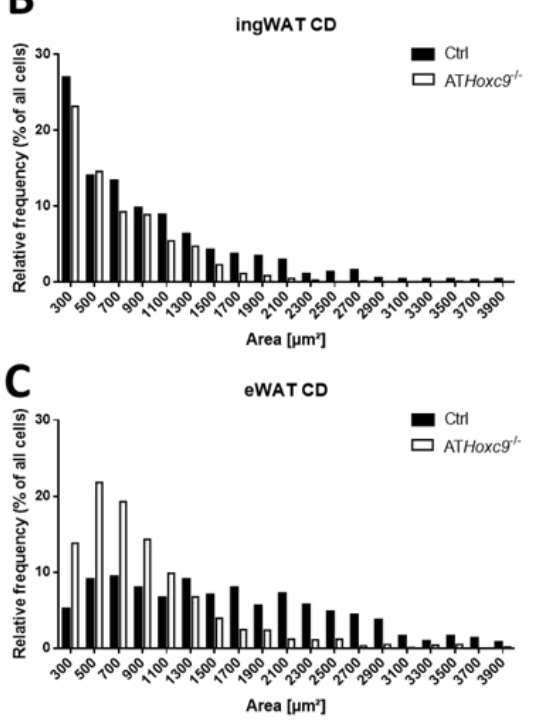

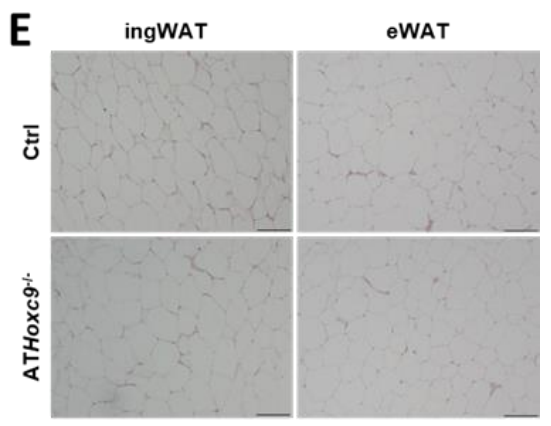

$\mathbf{F}$
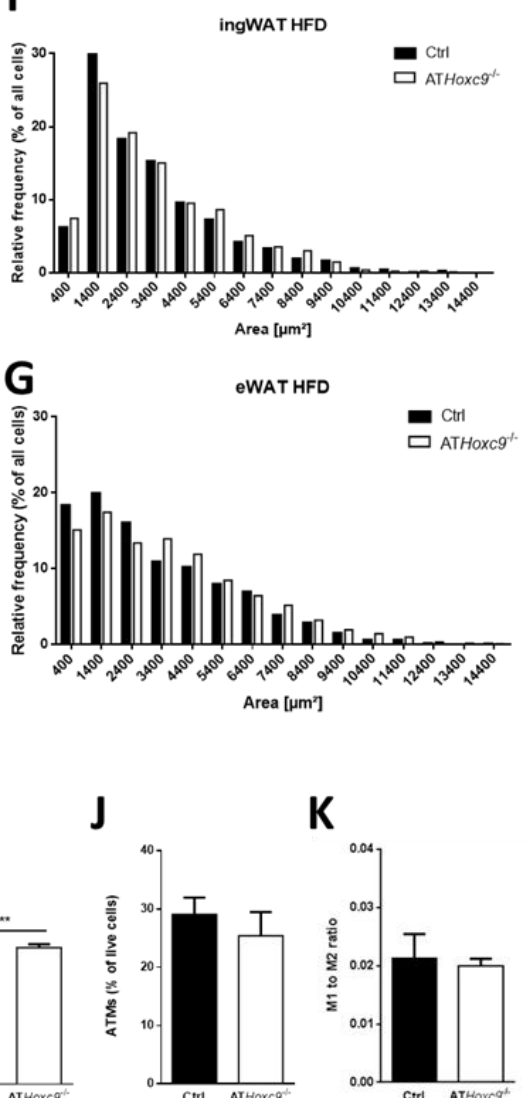

K

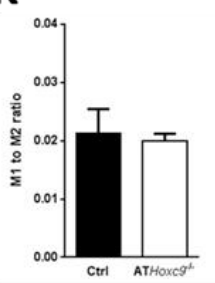

Figure 4. Consequences of Hoxc9 targeting on adipose tissue morphology. (A) H\&E staining of ingWAT and eWAT under chow diet (CD) Ctrl vs. ATHoxc ${ }^{-/}$. Ten times magnification, bar size $=100 \mu \mathrm{m}$. $(B, C)$ Adipocyte area measurements represented as fractions of total amount of counted cells. (D) Cell area measurements of ingWAT and eWAT from male mice under CD calculated with BZ-X800 Analyzer Software. n(ingWAT, Ctrl) $=1408, \mathrm{n}\left(\right.$ ingWAT, ATHoxc $\left.9^{-/}\right)=1676, \mathrm{n}(\mathrm{eWAT}, \mathrm{Ctrl})=752$, $\mathrm{n}\left(\mathrm{eWAT}, \mathrm{ATHoxc} \mathrm{9}^{-/-}\right)=1192$. (E) H\&E staining of ingWAT and eWAT under HFD Ctrl vs. ATHoxc9-1. Ten times magnification, bar size $=100 \mu \mathrm{m}$. $(\mathbf{F}, \mathbf{G})$ Adipocyte area measurements represented as fractions of total amount of counted cells. (H) Cell area measurements of ingWAT and eWAT from male mice under HFD calculated with BZ-X800 Analyzer Software. n(ingWAT, Ctrl) = 1137, $\mathrm{n}\left(\right.$ ingWAT, ATHoxc $\left.9^{-/-}\right)=1017, \mathrm{n}(\mathrm{eWAT}, \mathrm{Ctrl})=1394, \mathrm{n}\left(\mathrm{eWAT}, \mathrm{ATHoxc} 9^{--}\right)=1337$. (I-K) Analysis of the immune phenotype shows no differences with respect to adipose tissue macrophage (ATM) populations and the M1 to M2 macrophage ratio in lean male mice. Viable CD45+ (CD, Cluster of differentiation) and $\mathrm{F} 4 / 80^{+}$cells were defined as ATMs. Subpopulations could be further distinguished into M1 $\left(\mathrm{CD} 11 \mathrm{c}^{+} ; \mathrm{CD} 206^{-}\right)$and $\mathrm{M} 2\left(\mathrm{CD} 11 \mathrm{c}^{-} ; \mathrm{CD}^{206^{+}}\right)$. Viable $\mathrm{CD} 45^{+}$and $\mathrm{CD} 3^{+}$cells were defined as $\mathrm{T}$ lymphocytes, further divided into $\mathrm{T}$ helper cells $\left(\mathrm{T}_{\mathrm{H}} ; \mathrm{CD}^{+} ; \mathrm{CD}^{-}\right)$and cytotoxic $\mathrm{T}$ cells $\left(\mathrm{T}_{\mathrm{C}} ; \mathrm{CD}^{-}\right.$; $\left.\mathrm{CD}^{+}\right)$. Gating strategies are shown in Figure S3. $n=6-10$ mice each group. Data represent the mean \pm SEM. ${ }^{* *} p<0.01,{ }^{* * *} p<0.001$. 


\subsection{Male ATHoxc9-- Have Improved Glucose Tolerance Under High-Fat Diet}

Under chow-fed conditions, the parameters of energy expenditure were not different between ATHoxc ${ }^{-1-}$ and control mice (Figure 5A). However, the partial protection against HFD-induced obesity in male ATHoxc $9^{--}$mice could be caused by a trend towards higher energy expenditure during the light period (Figure 5B,C). In female ATHoxc9-/- mice, energy expenditure and activity levels were indistinguishable from control littermates (Supplementary Figure S4). In male ATHoxc $9^{-/-}$mice, spontaneous activity was higher under chow, whereas under HFD conditions, running distance was significantly lower compared to the control (Figure 5D). Rectal body temperature measurements did not reveal genotype differences between male mice under the same dietary conditions (Ctrl vs ATHoxc $9^{-/}$: $\mathrm{CD} 35.40 \pm 0.08^{\circ} \mathrm{C}$ vs. $34.50 \pm 1.62^{\circ} \mathrm{C}$, and HFD $36.88 \pm 1.00^{\circ} \mathrm{C}$ vs. $36.66 \pm 0.67^{\circ} \mathrm{C}$ ). Lower body weight in male ATHoxc $9^{-/}$mice upon HFD was associated with improved parameters of glucose metabolism including better glucose tolerance compared to controls at 25 weeks of age (Figure 5E and Table 1). However, HbA1c was not different between the groups (Table 1). Although insulin tolerance was not different between ATHoxc $9^{-/-}$and control mice, euglycemic-hyperinsulinemic clamp studies revealed a trend for improved insulin sensitivity in male ATHoxc9-- mice under chow diet (Figure 5F). We did not find significant ATHoxc9 genotype-related differences in circulating insulin, leptin, leptin-to-body weight ratio, adiponectin, nor serum lipid concentrations (Table 1).

Table 1. Serum concentrations of the parameters of lipid metabolism and glucose homeostasis. Measured in male mice at an age of 30 (CD) or 26 weeks (HFD).

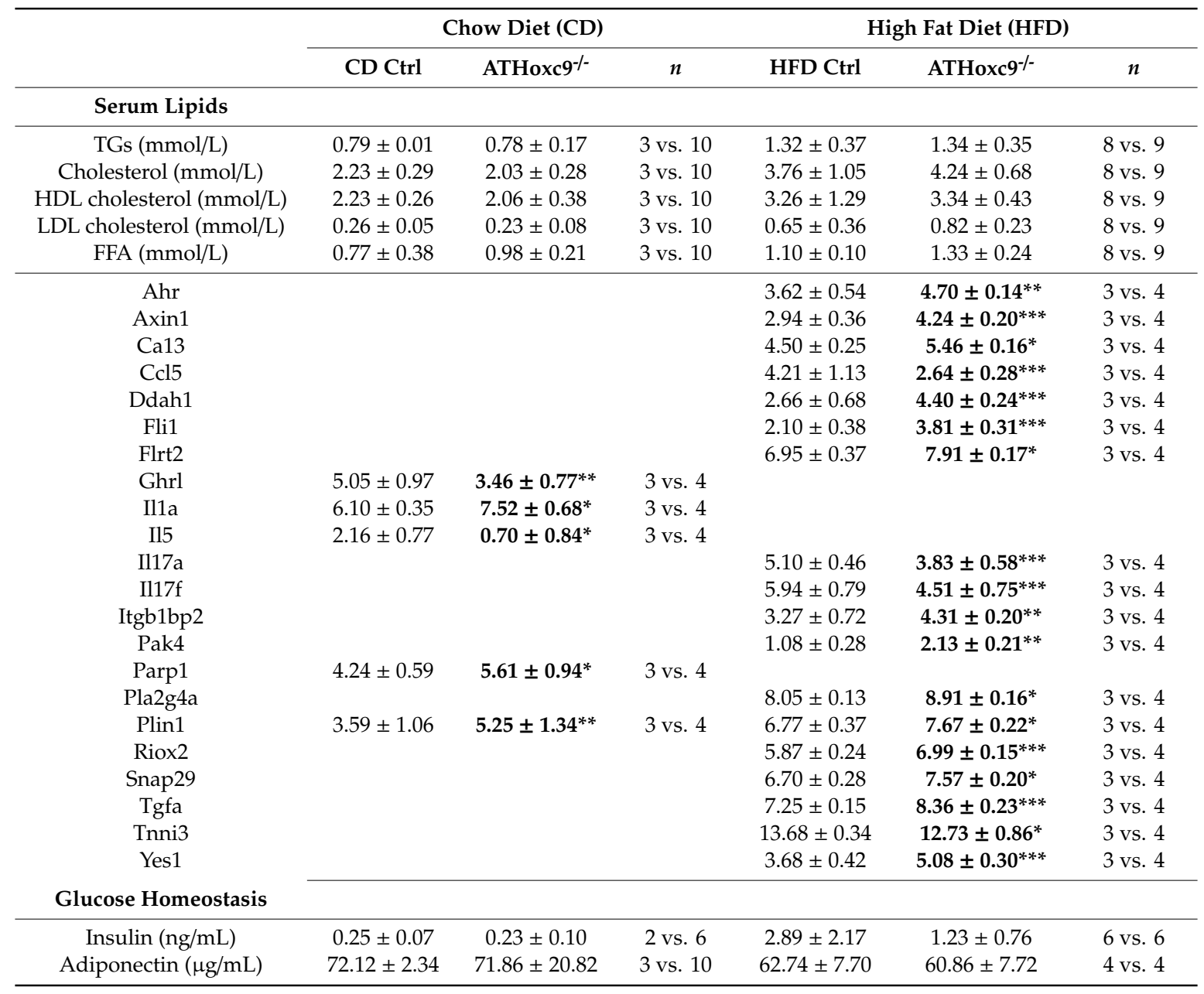


Table 1. Cont.

\begin{tabular}{ccccccc}
\hline & \multicolumn{3}{c}{ Chow Diet (CD) } & \multicolumn{3}{c}{ High Fat Diet (HFD) } \\
\cline { 2 - 7 } & CD Ctrl & ATHoxc9-/- & $n$ & HFD Ctrl & ATHoxc9-/- & $n$ \\
\hline Leptin (ng/mL) & $1.15 \pm 0.34$ & $1.48 \pm 0.89$ & 3 vs. 10 & $45.71 \pm 14.71$ & $29.50 \pm 21.53$ & 6 vs. 6 \\
Leptin/body weight & $0.039 \pm 0.011$ & $0.053 \pm 0.029$ & 3 vs. 10 & $1.08 \pm 0.38$ & $0.76 \pm 0.52$ & 6 vs. 6 \\
(ng/mL/g) & $4.17 \pm 0.62$ & $\mathbf{3 . 4 4} \pm \mathbf{0 . 4 0 ^ { * }}$ & 3 vs. 10 & $6.44 \pm 1.06$ & $5.62 \pm 1.88$ & 5 vs. 6 \\
Fasting glucose (mmol/L) & $4.67 \pm 0.24$ & $4.44 \pm 0.39$ & 2 vs. 10 & $4.35 \pm 0.10$ & $4.48 \pm 0.18$ & 7 vs. 7 \\
\hline HbA1c (\%) &
\end{tabular}

All values were obtained after a $16 \mathrm{~h}$ overnight fasting period. Significantly different values highlighted in bold. * Significantly different between Ctrl and $\mathrm{KO}$ animals of the same diet at $*<0.05,{ }^{* *} p<0.01, * * * p<0.001$. CD $=$ chow diet, $\mathrm{HFD}=$ high-fat diet, $\mathrm{Ctrl}=\mathrm{Hoxc} 9^{\text {lox } / \text { lox }}, \mathrm{KO}=\mathrm{ATHoxc} \mathrm{g}^{-1}$, $\mathrm{TGs}=$ triglycerides, $\mathrm{HDL}=$ high density lipoprotein, $\mathrm{LDL}=$ low density lipoprotein, $\mathrm{FFA}=$ free fatty acids, $\mathrm{HbA} 1 \mathrm{c}=$ glycated hemoglobin, $\mathrm{AU}=$ arbitrary units.
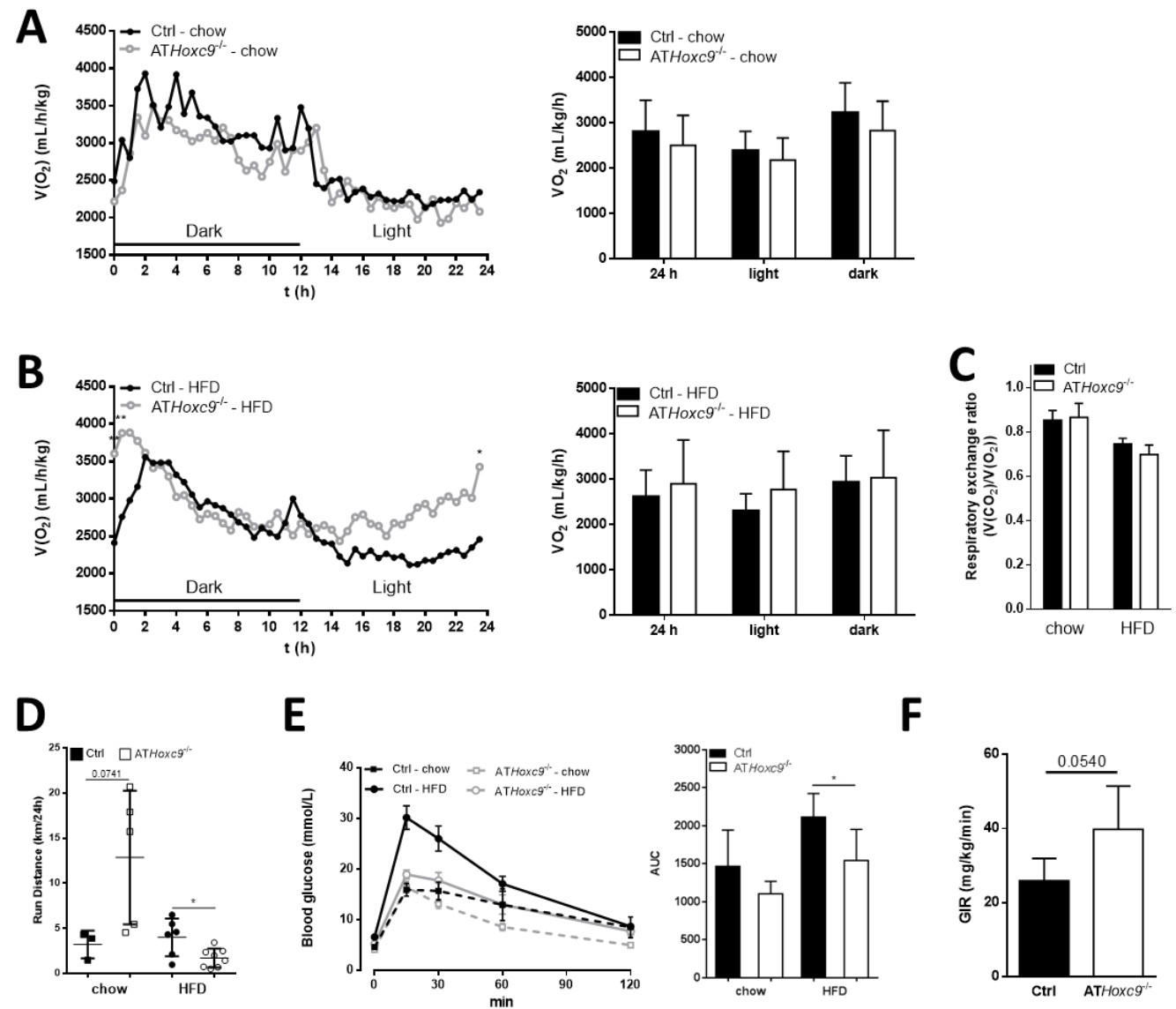

Figure 5. Metabolic parameters of ATHoxc 9 deficient mice. (A-C) Oxygen consumption and respiratory exchange rate (RER, C) were not altered by the presence or absence of Hoxc9 in AT in chow (A) or in HFD fed mice (B). (D) Run distance measurements revealed contrary results with respect to diet. Whereas chow-fed ATHoxc $9^{-/-}$mice tended to run more than littermate controls, they behaved oppositely under HFD. (E) Male ATHoxc $9^{-/-}$mice showed better glucose tolerance under HFD compared to control animals during intraperitoneal glucose tolerance tests (GTT) after 25 weeks of age. (F) Hyperinsulinemic-euglycemic clamps were performed in chow diet animals at 23-25 weeks of age to determine insulin sensitivity represented by the glucose infusion rate (GIR,). $n(A-C)=6-8$, $n(\mathbf{D}$ and $\mathbf{E})=4-10, n(\mathbf{F})=3-10$ mice each group. Data represent the mean \pm SEM. * Significantly different between Ctrl and ATHoxc $9^{-/-}$at $p<0.05$.

These results were consistent with AT Adipoq and Lep mRNA levels of male HFD mice (Table 2). Plin1 levels were higher in ATHoxc9-/- male mice under both diets. Under CD, only five out of 91 OLINK panel analyzed circulating proteins were different between the genotypes, whereas under HFD conditions, 18 parameters discriminated ATHoxc $9^{-/-}$from control mice (Table 1). 
Table 2. Gene expression measurements in ingWAT and eWAT of HFD male mice. Gene expression was normalized for $36 b 4$ gene expression as the housekeeping gene.

\begin{tabular}{cccc}
\hline \multicolumn{1}{c}{ Ctrl } & KO & $\boldsymbol{n}$ \\
\hline ingWAT & & \\
\hline Adipoq & $26.19 \pm 9.16$ & $24.88 \pm 12.10$ & 5 vs 6 \\
Dlk1 & $0.047 \pm 0.009$ & $0.043 \pm 0.017$ & 5 vs 6 \\
Fabp4 & $119.8 \pm 35.53$ & $\mathbf{8 5 . 1 4} \pm 27.56^{* *}$ & 5 vs 6 \\
Ki67 & $0.005 \pm 0.002$ & $0.004 \pm 0.003$ & 5 vs 6 \\
Lep & $3.87 \pm 1.93$ & $1.56 \pm 1.76$ & 5 vs 6 \\
Plin1 & $2.49 \pm 1.12$ & $2.84 \pm 1.32$ & 5 vs 6 \\
eWAT & & & \\
Adipoq & $25.41 \pm 10.57$ & $29.30 \pm 9.78$ & 5 vs 6 \\
Dlk1 & $0.029 \pm 0.022$ & $0.027 \pm 0.007$ & 5 vs 6 \\
Fabp4 & $89.47 \pm 18.99$ & $97.19 \pm 20.20$ & 5 vs 6 \\
Ki67 & $0.009 \pm 0.004$ & $0.009 \pm 0.003$ & 5 vs 6 \\
Lep & $4.98 \pm 1.52$ & $2.58 \pm 1.72$ & 5 vs 6 \\
Plin1 & $1.73 \pm 0.41$ & $2.27 \pm 0.76$ & 5 vs 6 \\
\hline
\end{tabular}

Significantly different values highlighted in bold. ${ }^{* *}$ Significantly different between Ctrl and KO animals of the same diet at $p<0.01$. ingWAT $=$ inguinal white adipose tissue, eWAT $=$ epigonadal adipose tissue, HFD $=$ high-fat diet, Ctrl $=$ Hoxc $9^{\text {lox } / \text { lox }}, \mathrm{KO}=$ ATHoxc $^{-1-}$.

\subsection{Fabp4 is Expressed Later than Hoxc9 During Adipogenesis}

Against our expectation from previously characterized Fabp4-Cre-mediated models [17,18], we did not find a sufficient number of ATHoxc $9^{-/-}$mice with a biologically relevant ablation of Hoxc9 in adipose tissue. We therefore systematically analyzed expression patterns of Hoxc9 and Fabp4 during adipogenesis both in different adipogenesis model systems in vitro and in ingWAT from newborn wild-type mice. Consistently, we found in immortalized adipocytes, 3T3-L1 cells, primary preadipocytes from wild-type mice and preadipocytes differentiated from newborn mice a maximum of Hoxc9 mRNA expression either at the $80 \%$ confluent stage or during initiation of differentiation at day 0 (Figure $6 \mathrm{~A}-\mathrm{C}$ ). In contrast, induction of Fabp 4 mRNA expression during adipogenesis only started between day 1 and day 2 (Figure 6A-C). In mature adipocytes, Hoxc 9 mRNA was only detectable at low expression levels, reaching a peak expression in ingWAT at days 5 and 10 after birth (Figure 6D). In contrast, Fabp 4 was lowly expressed from day 0 to day 10 and rose after day 15, when Hoxc9 mRNA was already dropped (Figure 6D). Differences between Hoxc9 and Fabp4 AT protein abundance during adipogenesis further implicated that Fabp4-mediated targeting strategies were not suitable to target genes expressed early during adipocyte development (Figure 6E). Whereas Fabp4 protein abundancy continuously increased with adipocyte maturation, Hoxc9 protein expression peaked between days 0 and 2 and from day 15 to day 20 with a nadir at day 5 and day 10 (Figure 6E). 


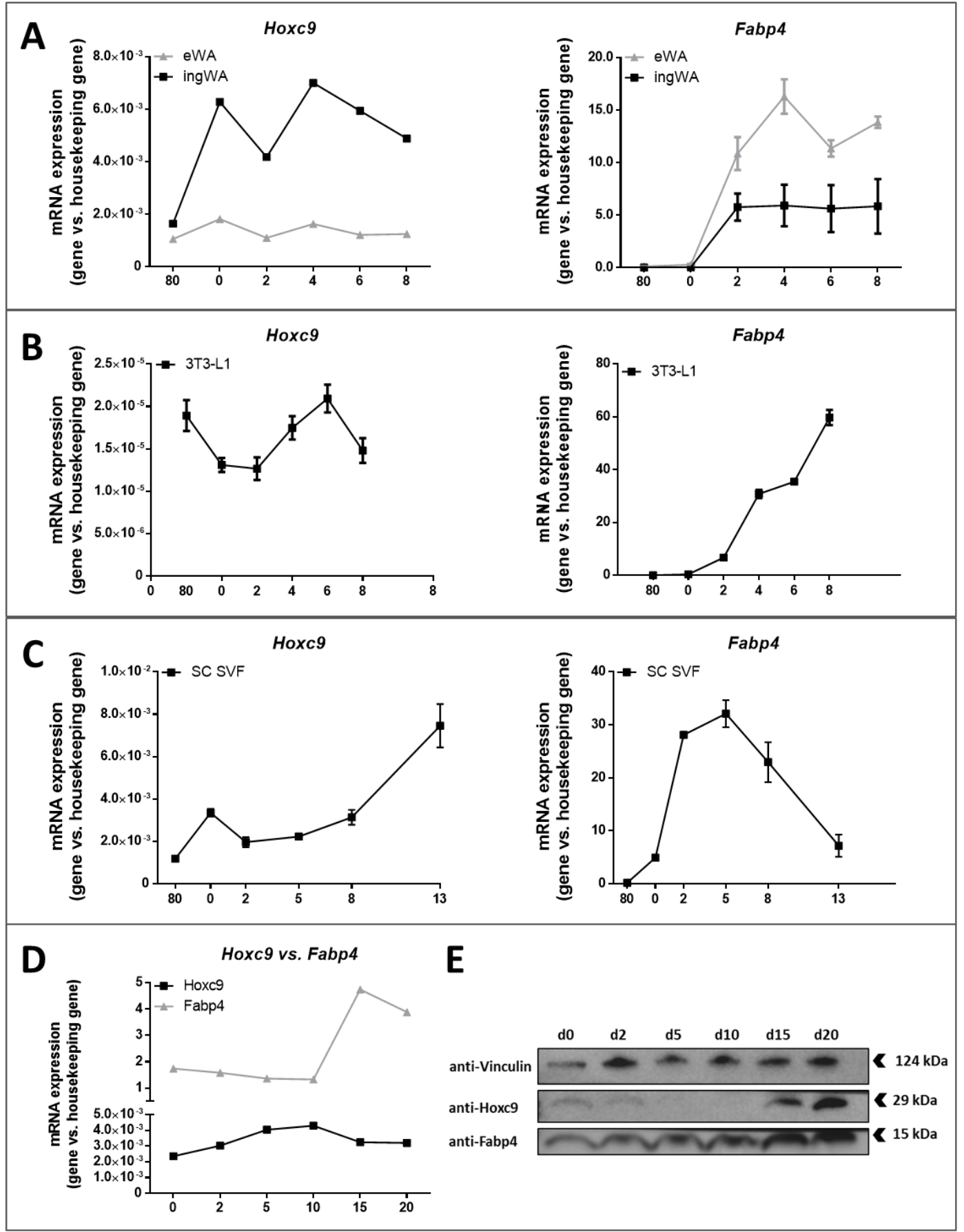

Figure 6. Gene and protein expression patterns of Hoxc9 and Fabp4 in different in vitro and in vivo models. All gene expression experiments were performed using LightCycler 480 and SybrGreen I assay. Mapped time points were at $80 \%$ pre-confluence (80), 100\% confluence, and initiation of differentiation (0) and days post-confluence (2-8 or 13, respectively). Expression values were relative to housekeeping gene expression levels. (A) Immortalized inguinal and epididymal adipocytes. Gene expression levels were related to 36B4 and Actb expression patterns. (B) 3T3-L1 cell line. Gene expression levels were related to $36 B 4$ and $A c t b$ expression patterns. (C) SVF cells isolated from ingWAT of C57BL/6NTac mice. Gene expression levels were related to 36B4, Ppia, and Himbs expression patterns. $n=2$. (D) Gene expression levels of Hoxc9 and Fabp4 in ingWAT. Expression levels were related to $36 b 4$ and $A c t b$ expression patterns. $n=2$ animals per time point. Data represented as the mean \pm SEM. (E) Representative Western blot of newborn male mice to determine protein levels during in vivo adipogenesis. Arrows represent the expected product size. 


\section{Discussion}

Developmental genes including Hoxc9 play an important role in the regulation of AT distribution and function $[6,7,19]$. Moreover, the anteroposterior expression pattern of Hoxc9 in mice indicates a relationship between anatomic localization, AT identity, and function [20]. Furthermore, it has been demonstrated that $\mathrm{Hoxc}_{9}$ is specifically expressed in white, but not in brown AT [6,21,22]. We therefore tested the hypothesis that AT-specific ablation of Hoxc9 in male and female ATHoxc9-- mice affects AT morphology, distribution, and function.

In general, Hoxc9 expression in AT was low and highly variable in both sexes, across different fat depots, but also in mice with the clearly distinguishable ATHoxc9-- genotype. Despite the heterogeneous efficacy of the Fabp4-Cre-mediated ATHoxc9 knockout, we continued our experiments comparing ATHoxc $9^{-/-}$to the control genotype. This decision was based on the assumption of obtaining a sufficient number of mice with the ATHoxc9-/- genotype and an effective ablation of ATHoxc9 to be included in our analyses. However, at the end of the studies, we were not able to select mice, which allowed discriminating the Hoxc9 genotype at the ATHoxc9 expression level.

Despite these shortcomings of the model, we found that male ATHoxc $9^{-/}$mice were partially protected against weight gain in response to HFD. Interestingly, reduced Hoxc9 expression was associated with a higher degree of adipocyte hypertrophy in eWAT after HFD. This observation supported human data describing negative correlations between Hoxc9 expression and adipocyte size even after adjusting for body fat mass [7]. Cells of the stromal vascular fraction express considerable amounts of Hoxc9 $[6,7,23]$. It is therefore important to note that the number of macrophages in AT was not different between AT from ATHoxc9-- and control mice.

Partial protection against HFD-induced weight gain in male ATHoxc $9^{-/}$mice was associated with improved glucose tolerance compared to controls. This result was in contrast to our findings in humans suggesting that lower AT Hoxc9 expression may be related to a phenotype with impaired glucose metabolism and insulin sensitivity [7].

The factors causing lower body weight in male ATHoxc $9^{-/}$mice were further explored following recently published guidance for the analysis of mouse energy metabolism [24]. Because food intake was not significantly different between ATHoxc ${ }^{-/-}$and control mice, we investigated energy expenditure in metabolic chambers. Indeed, ATHoxc $9^{-/}$mice displayed higher energy expenditure during the light phase, potentially underlying lower body weight gain upon HFD. In contrast, lower running activity and indistinguishable basal body temperature and brown AT mass did not explain the leaner phenotype of ATHoxc9-- after HFD.

Leptin secretion plays a role in the regulation of whole body energy metabolism and may contribute to the previously reported mouse strain differences in the response to HFD [25]. Moreover, leptin can stimulate locomotor activity [26]. However, circulating leptin levels were not different between ATHoxc $9^{-/}$and control mice. Taken together, our data suggest a role of Hoxc9 in the development of obesity and the determination of fat depot-specific signatures, which may affect whole body glucose metabolism, insulin sensitivity, and energy expenditure.

Independent of the diet, female ATHoxc $9^{-/-}$mice were not significantly different from controls with regard to body weight dynamics, parameters of AT function, morphology, and glucose metabolism. Sex-related factors such as circulating sex hormones and sex-hormone receptor expression [20] or differences in adipocytes metabolism and function [27] may explain the observed subtle sex differences in the phenotype of ATHoxc $9^{-/-}$mice.

Since the first mammalian Cre recombinases were used for gene targeting in 1992, Cre-loxP strategies have been commonly used to analyze gene functions [28-32]. There are several Cre recombinase models for the study of AT, which vary in efficiency and specificity for adipocytes [33]. Based on previous experience and the wide use of the model [9], we chose a Fabp4-Cre recombinase-mediated approach to target Hoxc9. We found that Hoxc9 AT expression was highly variable and not strictly correlated with the ATHoxc9-- genotype. The inefficiency of the Fabp4-Cre model has been reported for other target genes previously [31]. Importantly, analyses of animals 
selected for more efficient ATHoxc9 ablation did not reveal different phenotypes compared to the analyses by genotype.

The detected low Hoxc9 AT expression levels were consistent with previously reported AT Hoxc9 expression levels [32,34]. Additionally, Fabp4-Cre is expressed relatively late during adipogenesis [35,36]. Here, we analyzed endogenous expression patterns of both Hoxc9 and Fabp4 in an ex vivo and three independent in vitro model systems. All tested adipocyte models revealed that Hoxc9 was already expressed at early stages of adipogenesis, whereas Fabp4 expression only increased later during adipogenesis. This finding supported a recent argument that Fabp4-Cre is not suitable to investigate genes that exert their main effects during the early phase or even as initiation factors of adipogenesis [37]. Searching for an alternative Cre recombinase to target early expressed genes in (pre-) adipocytes, we examined adiponectin (Adipoq), as well as resistin (Retn) gene expression in our in vitro models (Figure S1). However, both alternative potential Cre promoter lines appeared to be equally unsuitable with regard to the expression profiles in relation to Hoxc9. Therefore, we would not expect a different outcome using the highly AT-specific Adipoq-Cre [38] or the less commonly used Retn-Cre [39]. Berry and Rodeheffer could demonstrate that white adipocyte precursor cells (APCs) were characterized by platelet-derived growth-factor receptor, alpha polypeptide (Pdgfra) expression [40]. These data suggested Pdgfra-Cre recombinase as an interesting target to delete Hoxc9 at early adipogenesis stages. Despite the fact that this model was not available to our group in the project planning phase, there are additional scientific caveats related to the use of this model. Pdgfra is expressed in several cells other than adipocytes, including tissues of neuroectodermal or mesenchymal origin [37], hepatocytes, and skeletal muscle cells [33].

Despite the shortcomings of the Fabp4-Cre-mediated Hoxc9 targeting, we found a genotype-phenotype association in male ATHoxc9-- mice after HFD-induced obesity. We therefore proposed that a moderate reduction in Hoxc9 gene expression may be sufficient to cause a lower weight gain in response to HFD. On the other hand, we could not exclude that the observed phenotype may be caused by independent and unknown mediators. In this context, it has been described that genetically identical C57BL/6J mice respond with a high degree of body weight variation to HFD [41]. Specific genotype-environment interactions [25] or variability in the intestinal uptake [42] may underlie heterogeneous response to diet challenges. In other studies, individual body weight differences in HFD response of C57BL/6J mice ranged from 27.2 to $52.7 \mathrm{~g}$ [43]. In addition, we could not exclude that differences in expression and activity of Fabp4-Cre recombinase may account for the heterogeneous efficacy in AT Hoxc9 ablation. It is noteworthy, that we did not formally prove this hypothesis, because Fabp4-Cre-expressing mice were not systematically studied as controls. However, decreased responsiveness for diet-induced obesity has been a repeated finding in Fabp4-Cre mice [44-46].

\section{Conclusions}

In conclusion, we found that crossing Hoxc9 floxed mice with Fabp4-Cre mice did not produce a biologically relevant ablation of $H o x c 9$ in adipose tissue and could therefore not be used to analyze the impact of Hoxc 9 on body weight regulation or in vivo adipose tissue function. Nevertheless, our data did not exclude a role of Hoxc9 in the development of obesity, AT distribution, and adipocyte function. The limitations of the Fabp4-Cre targeting strategy need to be considered particularly in the generation of models to investigate the function of developmental genes in AT.

Supplementary Materials: Supplementary materials can be found at http://www.mdpi.com/2227-9059/8/7/184/s1.

Author Contributions: Conceptualization, S.D. and M.B.; methodology, S.D. and N.K.; formal analysis, S.D.; investigation, S.D., C.B., A.K., M.K., and M.G.; visualization, S.D.; writing, original draft, S.D.; project administration, S.D.; resources, M.G., E.G.-J., P.K., N.K., and M.B.; supervision, E.G.-J. and M.B.; writing, review and editing, N.K. and M.B.; funding acquisition, M.B. All authors read and agreed to the published version of the manuscript. 
Funding: This work was funded by the Deutsche Forschungsgemeinschaft (DFG, German Research Foundation) through CRC 1052, Project Number 209933838, Subprojects B1 to M.B., B4 to N.K., and B3 to P.K., and Deutsches Zentrum für Diabetesforschung (DZD) to E.G.-J.

Acknowledgments: The authors would like to thank Jenny Schuster, Eva Böge, Lisa Gärtner, and Elisabeth Langer for excellent assistance at our animal facility. Further, we thank Viola Döbel for assistance with cell culture experiments, as well as Constance Hobusch and Kathrin Jäger for assistance with flow cytometry analysis. Special thanks go to John T. Heiker and Gerd Müller (both Leipzig University) for helpful discussions. We thank Johannes Klein (University of Lübeck, Germany) for providing the immortalized mouse cell lines.

Conflicts of Interest: The authors declare no conflict of interest.

\section{References}

1. Lewis, E.B. A gene complex controlling segmentation in Drosophila. Nature 1978, 276, 565-570. [CrossRef] [PubMed]

2. Lappin, T.R.J.; Grier, D.G.; Thompson, A.; Halliday, H.L. HOX genes: seductive science, mysterious mechanisms. Ulster Med. J. 2006, 75, 23-31. [PubMed]

3. Fröbius, A.C.; Matus, D.Q.; Seaver, E.C. Genomic organization and expression demonstrate spatial and temporal Hox gene colinearity in the lophotrochozoan Capitella sp. I. PLoS ONE 2008, 3, e4004. [CrossRef]

4. Castelli-Gair, J. Implications of the spatial and temporal regulation of Hox genes on development and evolution. Int. J. Dev. Biol. 1998, 42, 437-444.

5. McGinnis, W.; Garber, R.L.; Wirz, J.; Kuroiwa, A.; Gehring, W.J. A homologous protein-coding sequence in drosophila homeotic genes and its conservation in other metazoans. Cell 1984, 37, 403-408. [CrossRef]

6. Gesta, S.; Blüher, M.; Yamamoto, Y.; Norris, A.W.; Berndt, J.; Kralisch, S.; Boucher, J.; Lewis, C.; Kahn, C.R. Evidence for a role of developmental genes in the origin of obesity and body fat distribution. Proc. Natl. Acad. Sci. USA 2006, 103, 6676-6681. [CrossRef]

7. Brune, J.E.; Kern, M.; Kunath, A.; Flehmig, G.; Schön, M.R.; Lohmann, T.; Dressler, M.; Dietrich, A.; Fasshauer, M.; Kovacs, P.; et al. Fat depot-specific expression of HOXC9 and HOXC10 may contribute to adverse fat distribution and related metabolic traits. Obesity 2016, 24, 51-59. [CrossRef]

8. McGinnis, W.; Krumlauf, R. Homeobox genes and axial patterning. Cell 1992, 68, 283-302. [CrossRef]

9. He, W.; Barak, Y.; Hevener, A.; Olson, P.; Liao, D.; Le, J.; Nelson, M.; Ong, E.; Olefsky, J.M.; Evans, R.M. Adipose-specific peroxisome proliferator-activated receptor knockout causes insulin resistance in fat and liver but not in muscle. Proc. Natl. Acad. Sci. USA 2003, 100, 15712-15717. [CrossRef]

10. Abel, E.D.; Peroni, O.; Kim, J.K.; Kim, Y.B.; Boss, O.; Hadro, E.; Minnemann, T.; Shulman, G.I.; Kahn, B.B. Adipose-selective targeting of the GLUT4 gene impairs insulin action in muscle and liver. Nature 2001, 409, 729-733. [CrossRef] [PubMed]

11. Kern, M.; Kosacka, J.; Hesselbarth, N.; Brückner, J.; Heiker, J.T.; Flehmig, G.; Klöting, I.; Kovacs, P.; Matz-Soja, M.; Gebhardt, R.; et al. Liver-restricted Repin1 deficiency improves whole-body insulin sensitivity, alters lipid metabolism, and causes secondary changes in adipose tissue in mice. Diabetes 2014, 63, 3295-3309. [CrossRef] [PubMed]

12. Pfaffl, M.W. A new mathematical model for relative quantification.pdf. Nucleic Acids Res. 2001, 29. [CrossRef] [PubMed]

13. Braune, J.; Weyer, U.; Hobusch, C.; Mauer, J.; Brüning, J.C.; Bechmann, I.; Gericke, M. IL-6 Regulates M2 Polarization and Local Proliferation of Adipose Tissue Macrophages in Obesity. J. Immunol. 2017, 198, 2927-2934. [CrossRef] [PubMed]

14. Weiner, J.; Rohde, K.; Krause, K.; Zieger, K.; Klöting, N.; Kralisch, S.; Kovacs, P.; Stumvoll, M.; Blüher, M.; Böttcher, Y.; et al. Brown adipose tissue (BAT) specific vaspin expression is increased after obesogenic diets and cold exposure and linked to acute changes in DNA-methylation. Mol. Metab. 2017, 6, 482-493. [CrossRef]

15. Klein, J.; Fasshauer, M.; Klein, H.H.; Benito, M.; Kahn, C.R. Novel adipocyte lines from brown fat: A model system for the study of differentiation, energy metabolism, and insulin action. BioEssays 2002, 24, 382-388. [CrossRef]

16. Klein, J.; Benito, M.; Lowell, B.B.; Kahn, C.R.; Ito, M.; Fasshauer, M.; Ito, M.; Lowell, B.B.; Benito, M.; Kahn, C.R. $\beta 3$-Adrenergic stimulation differentially inhibits insulin signaling and decreases insulin-induced glucose uptake in brown adipocytes. J. Biol. Chem. 2002, 274, 34795-34802. [CrossRef] 
17. Blüher, M.; Michael, M.D.; Peroni, O.D.; Ueki, K.; Carter, N.; Kahn, B.B.; Kahn, C.R. Adipose tissue selective insulin receptor knockout protects against obesity and obesity-related glucose intolerance. Dev. Cell 2002, 3, 25-38. [CrossRef]

18. Klöting, N.; Koch, L.; Wunderlich, T.; Kern, M.; Ruschke, K.; Krone, W.; Brüning, J.C.; Blüher, M. Autocrine IGF-1 action in adipocytes controls systemic IGF-1 concentrations and growth. Diabetes 2008, 57, 2074-2082. [CrossRef]

19. Yamamoto, Y.; Tanahashi, T.; Kawai, T.; Chikahisa, S.; Katsuura, S.; Nishida, K.; Teshima-Kondo, S.; Sei, H.; Rokutan, K. Changes in behavior and gene expression induced by caloric restriction in C57BL/6 mice. Physiol. Genom. 2009, 39, 227-235. [CrossRef]

20. Gerdts, E.; Regitz-Zagrosek, V. Sex differences in cardiometabolic disorders. Nat. Med. 2019, 25, 1657-1666. [CrossRef]

21. Petrovic, N.; Walden, T.B.; Shabalina, I.G.; Timmons, J.A.; Cannon, B.; Nedergaard, J. Chronic peroxisome proliferator-activated receptor $\gamma(\operatorname{PPAR} \gamma)$ activation of epididymally derived white adipocyte cultures reveals a population of thermogenically competent, UCP1-containing adipocytes molecularly distinct from classic brown adipocytes. J. Biol. Chem. 2010, 285, 7153-7164. [CrossRef] [PubMed]

22. Timmons, J.A.; Wennmalm, K.; Larsson, O.; Walden, T.B.; Lassmann, T.; Petrovic, N.; Hamilton, D.L.; Gimeno, R.E.; Wahlestedt, C.; Baar, K.; et al. Myogenic gene expression signature establishes that brown and white adipocytes originate from distinct cell lineages. Proc. Natl. Acad. Sci. USA 2007, 104, 4401-4406. [CrossRef] [PubMed]

23. Yamamoto, Y.; Gesta, S.; Lee, K.Y.; Tran, T.T.; Saadatirad, P.; Kahn, R.C. Adipose depots possess unique developmental gene signatures. Obesity 2010, 18, 872-878. [CrossRef] [PubMed]

24. Tschöp, M.H.; Speakman, J.R.; Arch, J.R.S.; Auwerx, J.; Brüning, J.C.; Chan, L.; Eckel, R.H.; Farese, R.V.; Galgani, J.E.; Hambly, C.; et al. A guide to analysis of mouse energy metabolism. Nat. Methods 2012, 9, 57-63. [CrossRef]

25. Almind, K.; Kahn, C.R. Genetic determinants of energy expenditure and insulin resistance in diet-induced obesity in mice. Diabetes 2004, 53, 3274-3285. [CrossRef]

26. Coppari, R.; Ichinose, M.; Lee, C.E.; Pullen, A.E.; Kenny, C.D.; McGovern, R.A.; Tang, V.; Liu, S.M.; Ludwig, T.; Chua, S.C.; et al. The hypothalamic arcuate nucleus: A key site for mediating leptin's effects on glucose homeostasis and locomotor activity. Cell Metab. 2005, 1, 63-72. [CrossRef]

27. Keuper, M.; Berti, L.; Raedle, B.; Sachs, S.; Böhm, A.; Fritsche, L.; Fritsche, A.; Häring, H.U.; Hrabě de Angelis, M.; Jastroch, M.; et al. Preadipocytes of obese humans display gender-specific bioenergetic responses to glucose and insulin. Mol. Metab. 2019, 20, 28-37. [CrossRef]

28. Orban, P.C.; Chui, D.; Marth, J.D. Tissue- and site-specific DNA recombination in transgenic mice. Proc. Natl. Acad. Sci. USA 1992, 89, 6861-6865. [CrossRef]

29. Sternberg, N.; Hamilton, D. Bacteriophage P1 site-specific recombination. I. Recombination between loxP sites. J. Mol. Biol. 1981, 150, 467-486. [CrossRef]

30. Lakso, M.; Sauer, B.; Mosinger, B.; Lee, E.J.; Manningt, R.W.; Yu, S.-H.; Mulder, K.L.; Westphal, H. Targeted oncogene activation by site-specific recombination in transgenic mice (crellox/lens development/sinian virus 40 large tumor antigen). Proc. Nail. Acad. Sci. USA 1992, 89, 6232-6236. [CrossRef]

31. Schulz, T.J.; Glaubitz, M.; Kuhlow, D.; Thierbach, R.; Birringer, M.; Steinberg, P.; Pfeiffer, A.F.H.; Ristow, M. Variable expression of Cre recombinase transgenes precludes reliable prediction of tissue-specific gene disruption by tail-biopsy genotyping. PLOS ONE 2007, 2, 1-4. [CrossRef] [PubMed]

32. De Jong, J.M.A.; Larsson, O.; Cannon, B.; Nedergaard, J. A stringent validation of mouse adipose tissue identity markers. Am. J. Physiol. Endocrinol. Metab. 2015, 308, E1085-E1105. [CrossRef]

33. Jeffery, E.; Berry, R.; Church, C.D.; Yu, S.; Shook, B.A.; Horsley, V.; Rosen, E.D.; Rodeheffer, M.S. Characterization of Cre recombinase models for the study of adipose tissue. Adipocyte 2014, 3, $206-211$. [CrossRef] [PubMed]

34. Basse, A.L.; Dixen, K.; Yadav, R.; Tygesen, M.P.; Qvortrup, K.; Kristiansen, K.; Quistorff, B.; Gupta, R.; Wang, J.; Hansen, J.B. Global gene expression profiling of brown to white adipose tissue transformation in sheep reveals novel transcriptional components linked to adipose remodeling. BMC Genom. 2015, 16. [CrossRef] [PubMed]

35. Tontonoz, P.; Hu, E.; Spiegelman, B.M. Stimulation of adipogenesis in fibroblasts by PPAR $\gamma 2$, a lipid-activated transcription factor. Cell 1994, 79, 1147-1156. [CrossRef] 
36. Richard, A.J.; Stephens, J.M. The role of JAK-STAT signaling in adipose tissue function. Biochim. Biophys. Acta Mol. Basis Dis. 2014, 1842, 431-439. [CrossRef]

37. Krueger, K.C.; Costa, M.J.; Du, H.; Feldman, B.J. Characterization of cre recombinase activity for in vivo targeting of adipocyte precursor cells. Stem Cell Rep. 2014, 3, 1147-1158. [CrossRef]

38. Eguchi, J.; Wang, X.; Yu, S.; Kershaw, E.E.; Chiu, P.C.; Dushay, J.; Estall, J.L.; Klein, U.; Maratos-Flier, E.; Rosen, E.D. Transcriptional control of adipose lipid handling by IRF4. Cell Metab. 2011, 13, 249-259. [CrossRef]

39. Mullican, S.E.; Tomaru, T.; Gaddis, C.A.; Peed, L.C.; Sundaram, A.; Lazar, M.A. A Novel Adipose-Specific Gene Deletion Model Demonstrates Potential Pitfalls of Existing Methods. Mol. Endocrinol. 2013, 27, 127-134. [CrossRef]

40. Berry, R.; Rodeheffer, M.S. Characterization of the adipocyte cellular lineage in vivo. Nat. Cell Biol. 2013, 15, 302-308. [CrossRef]

41. Koza, R.A.; Nikonova, L.; Hogan, J.; Rim, J.S.; Mendoza, T.; Faulk, C.; Skaf, J.; Kozak, L.P. Changes in gene expression foreshadow diet-induced obesity in genetically identical mice. PLoS Genet. 2006, 2, 769-780. [CrossRef] [PubMed]

42. Keelan, M.; Hui, D.Y.; Wild, G.; Clandinin, M.T.; Thomson, A.B.R. Variability of the intestinal uptake of lipids is genetically determined in mice. Lipids 2000, 35, 833-837. [CrossRef] [PubMed]

43. Kammel, A.; Saussenthaler, S.; Jähnert, M.; Jonas, W.; Stirm, L.; Hoeflich, A.; Staiger, H.; Fritsche, A.; Häring, H.U.; Joost, H.G.; et al. Early hypermethylation of hepatic Igfbp2 results in its reduced expression preceding fatty liver in mice. Hum. Mol. Genet. 2016, 25, 2588-2599. [CrossRef] [PubMed]

44. Polak, P.; Cybulski, N.; Feige, J.N.; Auwerx, J.; Rüegg, M.A.; Hall, M.N. Adipose-Specific Knockout of raptor Results in Lean Mice with Enhanced Mitochondrial Respiration. Cell Metab. 2008, 8, 399-410. [CrossRef]

45. Chen, M.; Chen, H.; Nguyen, A.; Gupta, D.; Wang, J.; Lai, E.W.; Pacak, K.; Gavrilova, O.; Quon, M.J.; Weinstein, L.S. Gs $\alpha$ Deficiency in Adipose Tissue Leads to a Lean Phenotype with Divergent Effects on Cold Tolerance and Diet-Induced Thermogenesis. Cell Metab. 2010, 11, 320-330. [CrossRef]

46. Hofmann, S.M.; Zhou, L.; Perez-Tilve, D.; Greer, T.; Grant, E.; Wancata, L.; Thomas, A.; Pfluger, P.T.; Basford, J.E.; Gilham, D.; et al. Adipocyte LDL receptor-related protein-1 expression modulates postprandial lipid transport and glucose homeostasis in mice. J. Clin. Investig. 2007, 117, 3271-3282. [CrossRef] 